\title{
Does the Pressure on Increasing Wages Threaten the Profitability OF CZECH BAKERY?
}

\author{
Jakub Dyntar ${ }^{1}$; Dana Strachotová ${ }^{2}$ \\ University of Chemistry and Technology Prague, Department of Economics and Management \\ Technická 5, 16628 Prague, Czech Republic \\ e-mail: ${ }^{1}$ dyntarj@ vscht.cz; ${ }^{2}$ strachod@ vscht.cz
}

\begin{abstract}
This study describes the application of sensitivity analysis when determining the influence of wage growth on profitability of products made by a bakery in the Czech Republic. Sensitivity analysis of the profit was conducted for three best-selling products of the bakery: the loaf of bread, the roll and the bun using cost calculation of the products together with information about their sales and purchase prices of inputs in the production process in $2009-2017$. The results of the study show that wage growth was not the factor with the greatest impact on profitability of any of the three products. The most significant factors linked with the three products were their selling prices and flour purchase prices. Furthermore, it was proved that wage growth did not threaten any of the analyzed products in terms of their profitability.
\end{abstract}

\section{Keywords}

Sensitivity analysis; Food economics; Baking industry; Profitability analysis; Cost calculation.

\section{Introduction}

The baking industry in the Czech Republic currently faces a lack of qualified labor. The main reason is the direct wages that have been below-average in this industry for a long time: in 2017 they were around 18 thousand CZK/month [1]. The dynamics of direct wage growth has followed the development of the minimum wage (see [2]). Sales of bakeries are almost exclusively given by the demand in chain stores that try to push selling prices as low as possible [3]. By contrast, sales of bakery products in bakery-owned shops contribute to total sales only very little [4]. Additionally, the baking industry faces noticeable fluctuations of input purchase prices. This concerns particularly the purchase price of flour [5]. The above stated factors have fundamental impact on the profitability of bakery products.

In order to assess the impact of various factors on profitability, we can use sensitivity analysis [6]. The general procedure to be followed when conducting sensitivity analysis is stated in [7]. One-way sensitivity analysis is based on the presumption that in order to assess the sensitivity of the results it suffices to change only one factor, which is repeated with all other factors [8]. One-way sensitivity analysis can be applied in two ways [9]. The purpose of the first way is to find out how the value of the results is influenced by a change in one risk factor (e.g. by 10\%) and whether negatively or positively. The amount of the percentage is usually given by an expert estimate. Values of the results are subsequently repeated for all risk factors under all absolute and relative changes. The drawback of this procedure is the possibility that the amount of uncertainty in the risk factors used may actually differ to a great degree. The second way consists in compiling pessimistic and optimistic scenarios. Such scenarios are estimates of the actual status quo that are to be exceeded with preselected probability. This way allows for taking into account the different degree of uncertainty linked to various risk 
factors. The drawback is the necessity to quantify pessimistic and optimistic scenarios. Regardless of the way of sensitivity analysis it is apparent that significant risk factors will include absolutely big factors and very uncertain factors with a rather extensive interval of possible values [8]. The use of sensitivity analysis in food industry can be found, for instance, in [10] or [11].

\section{Goals of the Research}

1. To determine what influence direct wage growth has on the profitability of products made by a bakery in the Czech Republic. These products are a loaf of bread, a roll and a bun.

2. To compare the influence of direct wage growth has on the profitability with the influence of other factors such as selling prices of products, sold amounts of products and purchase prices of inputs including various types of flour and fuels.

3. To assess which factors can cause possible loss of the products profitability.

\section{$2 \quad$ Materials and Methods}

\subsection{Input Data for the Study}

According to [4] a typical representative of the Czech bakery market is a bakery whose annual turnover exceeds CZK 100 million and the number of its employees is between 100 and 500 .

Tab. 1: Cost calculation for the loaf of bread, the roll and the bun

\begin{tabular}{|c|c|c|c|c|c|}
\hline & \multicolumn{3}{|c|}{ Product $j$} \\
\hline & & & \multirow{2}{*}{$\begin{array}{c}1 \\
\text { Loaf of } \\
\text { Bread }\end{array}$} & \multirow{2}{*}{$\begin{array}{c}2 \\
\text { Roll } \\
\end{array}$} & \multirow{2}{*}{$\begin{array}{c}3 \\
\text { Bun } \\
\end{array}$} \\
\hline Category: Costs & $i$ & Cost item $c_{i}$ & & & \\
\hline \multirow{4}{*}{ Direct material } & 1 & Wheat bread flour & 2986 & 0 & 0 \\
\hline & 2 & Rye bread flour & 1886 & 0 & 0 \\
\hline & 3 & Wheat plain flour & 0 & 5552 & 5777 \\
\hline & 4 & Other ingredients & 1186 & 2308 & 2694 \\
\hline Direct wages & 5 & Direct wages & 1495 & 2990 & 2990 \\
\hline Other direct costs & 6 & Other direct costs & 507 & 1015 & 1015 \\
\hline \multirow{3}{*}{ Production overheads } & 7 & Electricity & 210 & 419 & 419 \\
\hline & 8 & Gas & 698 & 1397 & 1397 \\
\hline & 9 & Other production overheads & 1420 & 2840 & 2840 \\
\hline $\begin{array}{l}\text { Administration } \\
\text { overheads }\end{array}$ & 10 & Administration overheads & 3081 & 6162 & 6162 \\
\hline \multirow{3}{*}{ Distribution overheads } & 11 & Gasoline & 705 & 1405 & 1405 \\
\hline & 12 & Petrol & 144 & 286 & 286 \\
\hline & 13 & $\begin{array}{ll}\begin{array}{l}\text { Other } \\
\text { overheads }\end{array} & \text { distribution } \\
\end{array}$ & 2415 & 4814 & 4814 \\
\hline \multicolumn{3}{|c|}{ Total full costs of a performance [CZK / $t$ of a Product] } & 16732 & 29187 & 29798 \\
\hline
\end{tabular}

Source: Own

The input data for the study were provided by a bakery carrying out its business in the Czech Republic for 3 products with the highest impact on the revenues (i.e. $80 \%$ of total amount of products sold and $60 \%$ of total revenues). These products are a loaf of bread, a roll and a bun. The input data contain sold amounts of products and their selling prices, purchase prices of wheat plain flour, wheat bread flour, rye bread flour, diesel, petrol, gas and electricity. 
Furthermore, the development of the direct wages for each product was provided. All input data cover the time period 2009 - 2017. For the loaf of bread, the roll, and the bun, the bakery provided a cost calculation structured in Table 1 . The production capacity of the bakery was considered to be 2880 tons of loaves of bread per year, 620 tons of rolls per year and 450 tons of buns per year.

\subsection{Sensitivity Analysis of the Profit}

We applied one-way sensitivity analysis described in [12] to assess the influence of different factors on the profit of the loaf of bread, the roll and the bun. These factors and their average $\left(A V G f_{k}\right)$, minimum $\left(M I N f_{k}\right)$ and maximum $\left(M A X f_{k}\right)$ values are shown in Table 2.

Tab. 2: Factors used in the sensitivity analysis of the profit

\begin{tabular}{|c|c|c|c|c|c|c|c|}
\hline$k$ & Factor $f_{k}$ & $M I N f_{k}$ & $A V G f_{k}$ & $M A X f_{k}$ & $\begin{array}{c}\min \Delta f_{k} \\
\%\end{array}$ & $\begin{array}{c}\max _{\%} f_{k} \\
\end{array}$ & $\begin{array}{c}\Delta f_{k} \\
\%\end{array}$ \\
\hline 1 & Purchase price of wheat plain flour $[\mathrm{CZK} / \mathrm{t}]$ & 5534 & 6959 & 8504 & 20 & 22 & 25 \\
\hline 2 & Purchase price of wheat bread flour $[\mathrm{CZK} / \mathrm{t}]$ & 4940 & 6633 & 8267 & 26 & 25 & 30 \\
\hline 3 & Purchase price of rye bread flour $[\mathrm{CZK} / \mathrm{t}]$ & 5288 & 7049 & 8636 & 25 & 23 & 25 \\
\hline 4 & Purchase price of diesel [CZK/l] & 24.7 & 32.0 & 37.2 & 23 & 16 & 20 \\
\hline 5 & Purchase price of petrol [CZK/l] & 25.2 & 34.2 & 40.1 & 26 & 17 & 25 \\
\hline 6 & Purchase price of electricity [CZK/MWh] & 2505 & 2672 & 2894 & 6 & 8 & 10 \\
\hline 7 & Purchase price of gas [CZK/MWh] & 737 & 857 & 1002 & 14 & 17 & 20 \\
\hline 8 & Selling price of a loaf of bread $[\mathrm{CZK} / \mathrm{pc}]$ & 19.2 & 21.2 & 22.6 & 10 & 6 & 10 \\
\hline 9 & Selling price of a roll $[\mathrm{CZK} / \mathrm{pc}]$ & 1.4 & 1.5 & 1.6 & 8 & 8 & 10 \\
\hline 10 & Selling price of a bun $[\mathrm{CZK} / \mathrm{pc}]$ & 1.2 & 1.6 & 1.7 & 22 & 9 & 20 \\
\hline 11 & Amount of loaves of bread sold [t] & 1649 & 2190 & 2676 & 25 & 22 & 25 \\
\hline 12 & Amount of rolls sold [t] & 516 & 550 & 595 & 6 & 8 & 10 \\
\hline 13 & Amount of buns sold $[\mathrm{t}]$ & 355 & 393 & 433 & 10 & 10 & 10 \\
\hline 14 & Direct wages - loaf of bread [CZK/pc] & 1.68 & 2.00 & 2.62 & 16 & 31 & 25 \\
\hline 15 & Direct wages - roll [CZK/pc] & 0.12 & 0.14 & 0.19 & 16 & 31 & 25 \\
\hline 16 & Direct wages - bun $[\mathrm{CZK} / \mathrm{pc}]$ & 0.14 & 0.17 & 0.22 & 16 & 32 & 25 \\
\hline
\end{tabular}

Source: Own

The average, minimum and maximum values of the factors were obtained from the input data for the study provided by the bakery. Using the average and minimum values of the factors we determined their relative change $\left(\min \Delta f_{k}\right)$ as:

$$
\min \Delta \mathrm{f}_{\mathrm{k}}=\frac{\mathrm{AVGf}_{\mathrm{k}}-\mathrm{MINf}_{\mathrm{k}}}{\mathrm{AVGf}_{\mathrm{k}}} \cdot 100 \%
$$

Similarly, we used the average and maximum values of the factors to determine their relative change $\left(\max \Delta f_{k}\right)$ as:

$$
\max \Delta \mathrm{f}_{\mathrm{k}}=\frac{\operatorname{MAXf}_{\mathrm{k}}-A V G f_{k}}{\operatorname{AVGf}_{\mathrm{k}}} \cdot 100 \%
$$

Using $\min \Delta f_{k}$ and $\max \Delta f_{k}$ we determined $\Delta f_{k}$ for each $f_{k}$ as:

$$
\Delta \mathrm{f}_{\mathrm{k}}=\frac{\min \Delta \mathrm{f}_{\mathrm{k}}+\max \Delta \mathrm{f}_{\mathrm{k}}}{2}
$$


The value of $\Delta f_{k}$ was rounded up to the nearest multiple of $5 \%$ following a recommendation stated in [9].

The initial value of profit $z_{j}$ for $j^{\text {th }}$ product was obtained as:

$$
\mathrm{z}_{j}=Q_{j} \cdot\left(p_{j}-\sum_{i=1}^{13} c_{i j}\right)
$$

where $p_{j}$ is the average selling price of $j^{\text {th }}$ product in $2009-2017$ and $Q_{j}$ is the average annual amount of $j^{\text {th }}$ product sold in the same period. We assumed $1 \mathrm{pc}$ of the loaf of bread to weigh $1.2 \mathrm{~kg}, 1 \mathrm{pc}$ of the roll $0.043 \mathrm{~kg}$ and $1 \mathrm{pc}$ of the bun $0.05 \mathrm{~kg}$.

We used $\Delta f_{k}$ values to define scenarios to be tested in the one-way sensitivity analysis of the profit. Every tested scenario consisted in increasing the $k^{\text {th }}$ factor by $\Delta f_{k}$ and calculating the profit change $\max \Delta z_{j}$ as compared with the initial value of the profit $z_{j}$. In case of factors derived from cost items (i.e. factors $\mathrm{f}_{1}-\mathrm{f}_{7}$ and $\mathrm{f}_{14}-\mathrm{f}_{16}$ ) $\max \Delta z_{j}$ was calculated as:

$$
\max \Delta \mathrm{z}_{j}=Q_{j} \cdot\left(p_{j}-\sum_{i=1}^{k-1} c_{i j}-\left(1+f_{k}\right)-\sum_{i=k+1}^{13} c_{i j}\right)-z_{j}
$$

In the case of factors derived from the selling prices of products (i.e. factors $\mathrm{f}_{8}-\mathrm{f}_{10}$ ) $\max \Delta z_{j}$ was calculated as:

$$
\max \Delta \mathrm{z}_{j}=Q_{j} \cdot\left[\left(1+f_{k}\right) \cdot p_{j}-\sum_{i=1}^{13} c_{i j}\right]-z_{j}
$$

In the case of factors derived from the amount of products sold (i.e. factors $\mathrm{f}_{11}-\mathrm{f}_{13}$ ) $\max \Delta z_{j}$ was calculated as:

$$
\max \Delta \mathrm{z}_{j}=\left(1+f_{k}\right) \cdot Q_{j} \cdot\left(p_{j}-\sum_{i=1}^{13} c_{i j}\right)-z_{j}
$$

Using $\max \Delta z_{j}$, the value of $\min \Delta z_{j}$ was calculated for every scenario as:

$$
\min \Delta \mathrm{z}_{j}=z_{j}-\max \Delta \mathrm{z}_{j}
$$

For the loaf of bread, 9 different scenarios were tested differing in that always just one factor out of the factor group $\mathrm{f}_{2}-\mathrm{f}_{8}, \mathrm{f}_{11}$ and $\mathrm{f}_{14}$ was changed. For the roll, 8 scenarios were tested differing in that always just one factor out of the factor group $f_{1}, f_{4}-f_{7}, f_{9}, f_{12}$ and $f_{15}$ was changed. Finally for the bun, 8 scenarios were tested differing in that always just one factor out of the factor group $\mathrm{f}_{1}, \mathrm{f}_{4}-\mathrm{f}_{7}, \mathrm{f}_{10}, \mathrm{f}_{13}$ and $\mathrm{f}_{16}$ was changed.

\section{$3 \quad$ Results and Discussion}

Based on the values of $\max \Delta z_{j}$ and $\min \Delta z_{j}$, Fig. 1, Fig. 2 and Fig. 3 show the sensitivity of the profit for the loaf of bread, the roll and the bun. 


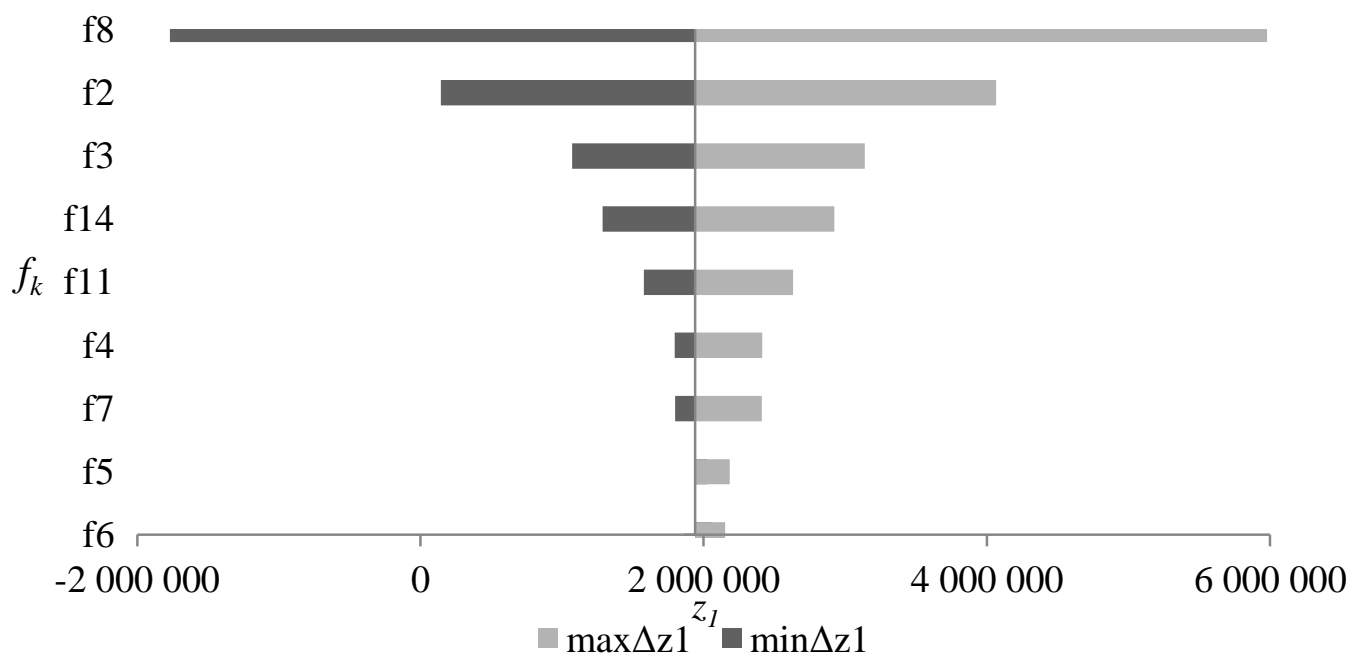

Source: Own

Fig. 1: Sensitivity analysis of the profit - the loaf of bread

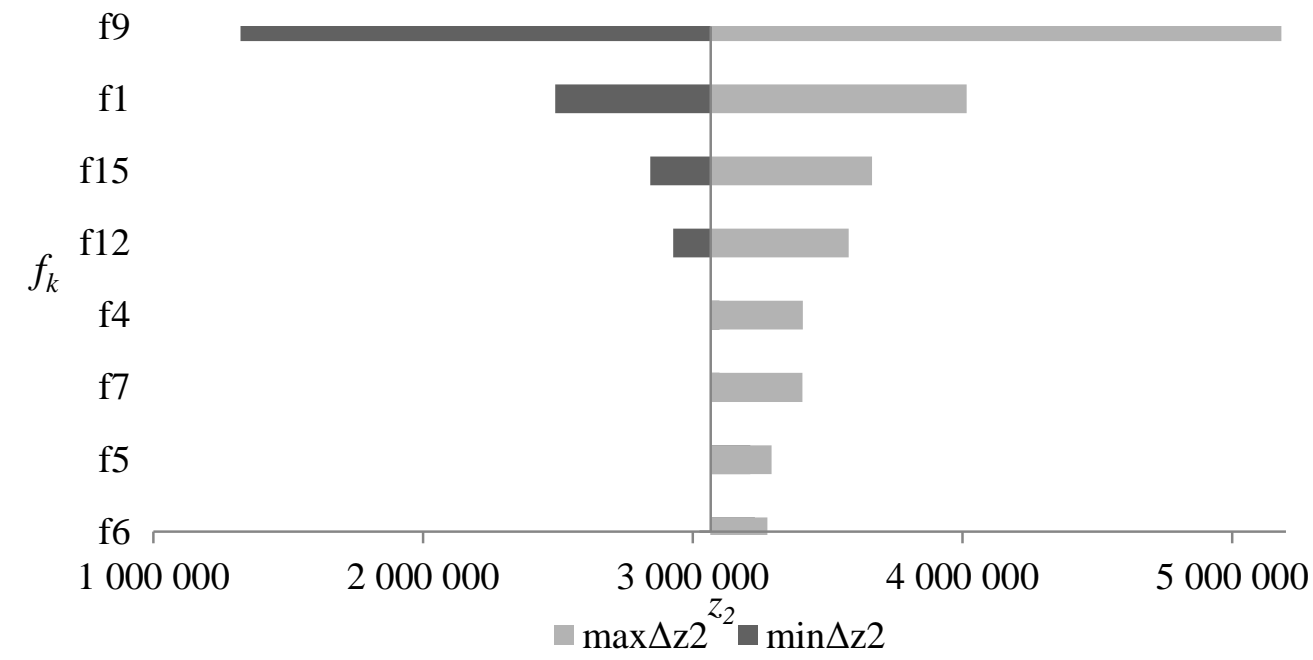

Source: Own

Fig. 2: Sensitivity analysis of the profit - the roll

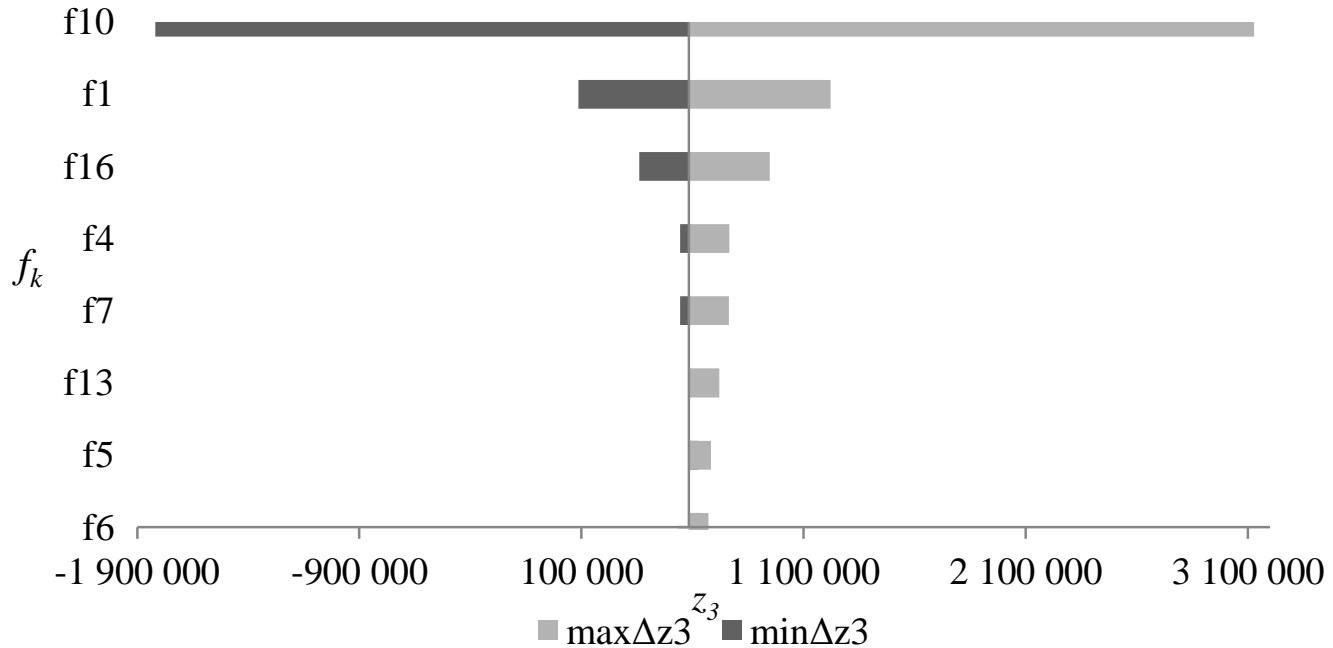

Source: Own

Fig. 3: Sensitivity analysis of the profit - the bun 
In case of the loaf of bread the factor with greatest influence on profit is the selling price of the product followed by the purchase prices of wheat and rye bread flour. This is in accordance with [13]. Direct wages have similar impact on profitability as the price of rye flour. The amount of the product sold is of much less importance, while other considered factors only have marginal influence. In the case of selling price of the product and purchase price of wheat bread flour, a negative change in these factors to values around $\Delta f_{k}$ leads to possible loss of the product profitability.

Similarly, also in the case of the roll the factor that has the most significant impact on profitability is the selling price of the product followed by the purchase price of wheat plain flour. Also in this case the results are in accordance with [13]. Unlike in the case of bread, the less significant factors influencing profitability of the roll are direct wages together with the amount of the product sold. None of the other factors can be expected to have negative impact on profitability. A percentage growth or drop in the values of the other tested factors did not result in values anywhere near $\Delta f_{k}$ or in possible loss of the product profitability.

Finally, in the case of the bun the factor that has the most significant influence is again the selling price of the product. Also in this case the most significant factor is in accordance with [13]. What may have certain influence on profit can be the purchase price of wheat plain flour and direct wages. Other marginal factors influencing profitability of this product can also be the amount of the product sold. In the case of the selling price of a bun, a percentage growth in the product price leads to a percentage growth of this factor to values around $\Delta f_{k}$ and to possible loss of the product profitability.

\section{Conclusion}

1. In all observed products, i.e. the loaf of bread, roll and bun the direct wage growth is not the most significant factor in terms of its influence on profitability.

2. The percentage growth of direct wages to values around $\Delta f_{k}$ does not threat any of the products from the perspective of their profitability.

3. The biggest threat that may hinder bakeries from achieving satisfactory effectiveness lies in maintaining acceptable selling prices of the products.

\section{Literature}

[1] GÉBLOVÁ, A.: Úspěšný pekař musí stále dobře počítat. Statistika\&My. 2017, Vol. 7 Issue 1, pp. 26-27. ISSN 1804-7149.

[2] MPSV ČR: Vývoj minimální mzdy od jejího zavedení v roce 1991. [online]. 2018. [accessed 2018-05-28]. Available from: https://www.mpsv.cz/cs/871

[3] CHLÁDKOVÁ, H.; KUDOVÁ, D.: Situation analysis of the external environment of a bakery company. Agricultural Economics. 2008, Vol. 54, Issue 7, pp. 301-306. ISSN 0139-570X. DOI: 10.17221/2706-AGRICECON

[4] RUSŇÁKOVÁ, E.: Pekárenský obor v ČR: (komplexní hodnocení oboru za období 2008-2012). Ústav zemědělské ekonomiky a informací, Praha, 2013. ISBN 978-807271-204-5.

[5] DŘÍZAL, J.: Pekařský cenový monitoring. [online]. 2016. [accessed 2018-05-28]. Available from WWW: http://www.svazpekaru.cz/attachments/157_pc8\%20monitoring.pdf

[6] FOTR, J.: Jak hodnotit a snižovat podnikatelské riziko. Management press, Praha, 1992. ISBN 80-85603-06-3. 
[7] SAltelli, A.; TARANTOLA, S.; CAMPOLONGO, F.; RATTO, M.: Sensitivity Analysis in Practice: A Guide to Assessing Scientific Models. John Wiley \& Sons, Ltd, 2004. ISBN 9780470870938. DOI: $\underline{10.1002 / 0470870958}$

[8] SALTELLI, A.: Sensitivity Analysis for Importance Assessment. Risk Analysis. 2002, Vol. 22, Issue 3, pp. 579-590. DOI: $\underline{10.1111 / 0272-4332.00040}$

[9] FOTR, J.; SOUČEK, I.: Investiční rozhodování a řizení projektů: Jak připravovat, financovat a hodnotit projekty, ř́dit jejich riziko a vytváret portfolio projektů. Grada Publishing, Praha, 2010. ISBN 978-80-247-3293-0.

[10] YUAN, Y.; YONGMING, Y.; YUNYUN, D.; YUNCHONG, G.: Economic profitability of tilapia farming in China. Aquaculture International. 2017, Vol. 25, Issue 3, pp. 1253-1264. DOI: 10.1007/s 10499-017-0111-8

[11] Van Den BURG, S. W. K.; Van DUIJN, A. P.; BARTELINGS, H.; Van KRIMPEN, M. M.; POELMAN, M.: The economic feasibility of seaweed production in the North Sea. Aquaculture Economics and Management. 2016, Vol. 20, Issue 3, pp. 235-252. DOI: $10.1080 / 13657305.2016 .1177859$

[12] FREY, H., Ch; PATIL, S. R.: Identification and Review of Sensitivity Analysis Methods. Risk Analysis. 2002, Vol. 22, Issue 3, pp. 553-578. ISSN 1539-6924. DOI: $\underline{10.1111 / 0272-4332.00039}$

[13] DYNTAR, J.; STRACHOTOVÁ, D.: Sensitivity analysis of profit of a bakery operating in the Czech Republic. In: Knowledge for market use 2017: People in economics decisions, behavior and normative models. Palacký University Olomouc, Olomouc, 2017, pp. 1122-1131. ISBN 978-80-244-5233-3.

Jakub Dyntar, M.Sc., Ph.D.; Dana Strachotová, M.Sc., Ph.D. 


\section{OHROŽUJE TLAK NA RŮST MEZD ZISKOVOST PRODUKTU゚ PRŮMYSLOVÉ PEKÁRNY PODNIKAJÍCÍ V ČESKÉ REPUBLICE?}

V této studii popisujeme aplikaci analýzy citlivosti při stanovení vlivu růstu mezd na ziskovost produktů průmyslové pekárny podnikající v České republice. Analýza citlivosti zisku je provedena pro 3 nejprodávanější výrobky průmyslové pekárny, kterými jsou bochník chleba, rohlík a houska s využitím nákladových kalkulací výrobků a také informací o prodejích výrobků a nákupních cenách vstupů do výrobního procesu v období $2009-2017$. Výsledky studie ukazují, že u všech zkoumaných výrobků nepředstavuje růst mezd nejvýznamnější faktor $\mathrm{z}$ hlediska vlivu na ziskovost. Nejvýznamnějšími faktory u všech zkoumaných výrobků jsou jejich prodejní ceny a také nákupní ceny mouky. Dále bylo prokázáno, že růst mezd neohrožuje žádný ze zkoumaných výrobků z pohledu jejich rentability.

\section{BEDROHT DER DRUCK AUF DIE LÖHNE DIE RENTABILITÄT VON PRODUKTEN EINER IN TSCHECHIEN TÄTIGEN INDUSTRIEBÄCKEREI?}

Diese Studie beschreibt die Anwendung der Sensitivitätsanalyse bei Ermittlung des Einflusses der Lohnsteigerung auf Rentabilität von Produkten einer in Tschechien tätigen Industriebäckerei. Die Sensitivitätsanalyse wurde bei den drei meistverkauften Produkten der Industriebäckerei - Laib Brot, Hörnchen und Brötchen - durchgeführt. Dabei wurden die Kostenkalkulationen einzelner Produkte herangezogen und auch Informationen über die Verkaufszahlen der Produkte und über die Einkaufspreise der Inputs, die in den Jahren 2009 2017 in den Produktionsprozess eingingen. Die Ergebnisse der Studie zeigen, dass die Lohnsteigerung bei den geprüften Produkten aus Sicht des Einflusses auf ihre Rentabilität nicht den wichtigsten Faktor darstellt. Die wichtigsten Faktoren bei allen geprüften Produkten sind ihre Verkaufspreise sowie die Einkaufspreise von Mehl. Ferner wurde nachgewiesen, dass die Lohnsteigerung die Rentabilität keines der drei geprüften Produkte bedroht.

\section{CZY PRESJA NA WZROST PŁAC ZAGRAŻA RENTOWNOŚCI PRODUKTÓW PIEKARŃ PRZEMYSŁOWYCH, DZIAŁAJĄCYCH W CZESKIEJ REPUBLICE?}

W niniejszym opracowaniu opisujemy stosowanie analizy wrażliwości podczas określania wpływu wzrostu płac na rentowność produktów piekarni przemysłowej, działającej w Czeskiej Republice. Analiza wrażliwości zysku przeprowadzona została w przypadku 3 najlepiej się sprzedających produktów piekarni przemysłowej, którymi są bochenek chleba, rogalik i bułka z wykorzystaniem kalkulacji kosztów produktów oraz informacji o sprzedaży produktów we wstępnych cenach zakupu do procesu produkcji w okresie lat $2009-2017$. Wyniki badań pokazują, że u żadnego z badanych wyrobów wzrost płac nie przedstawia najważniejszego czynnika z punktu widzenia jego wpływu na rentowność. Najważniejszymi faktorami u wszystkich badanych wyrobów są ceny ich sprzedaży oraz ceny zakupu mąki. Wykazano poza tym, że wzrost płac nie zagraża żadnemu z badanych wyrobów z punktu widzenia jego rentowności. 